\title{
Transition from CLSI to EUCAST: How our antibiotic susceptibility tests will be affected
}

\section{CLSI'den EUCAST'a geçiș: Antibiyotik duyarlılık testlerimiz nasıl etkilenecek}

Gülșen HAZIROLAN ${ }^{1}$ (ID)

\section{ABSTRACT}

Objective: Two standard guidelines are commonly used worldwide. In our country CLSI guidelines have been used up to recent years, but currently, a transition to EUCAST standards has begun in many centers. In this study the effect of transition from CLSI guideline to EUCAST guideline on antibiotic susceptibility test (AST) reports in a high prevalence region for antibiotic resistance was investigated.
\end{abstract}

Methods: Non-duplicated 5003 isolates (1902 Enterobacteriaceae, 1261 Acinetobacter baumannii, 697 Pseudomonas aeruginosa, 424 Staphylococcus aureus, 336 Enterococcus faecalis, 257 Enterococcus faecium, and 126 Stenotrophomonas maltophilia) isolated from the samples sent from intensive care units (ICUs) were included in the study. The identifications of the microorganisms were performed with Bruker Microflex MS (Bruker Daltonics, Bremen, Germany) system, and their AST were evaluated with Phoenix automated system (BD, Sparks, MD, USA). The MIC values were interpreted according to the breakpoints indicated in CLSI and EUCAST guidelines.

Results: The highest resistance increase among Enterobacteriacea was seen to beta lactam/ betalactamase inhibitor combinations, followed by

\section{ÖZET}

Amaç: Antibiyotik duyarlılık testlerinde iki standart kılavuz tüm dünyada yaygın olarak kullanılmaktadır. Ülkemizde son yıllara kadar CLSI kılavuzu kullanılmakta iken, günümüzde birçok merkezde EUCAST kılavuzuna geçildi. Bu çalışmada, antibiyotik direnci açısından yüksek prevalanslı bir merkezde CLSI kılavuzundan EUCAST kılavuzuna geçişin antibiyotik duyarlılık test (AST) raporlarına etkisi araștırıldı.

Yöntem: Yoğun bakım ünitesinden gönderilen örneklerden izole edilen tekrar içermeyen 5.003 izolat (1.902 Enterobacteriaceae, 1.261 Acinetobacter baumannii, 697 Pseudomonas aeruginosa, 424 Staphylococcus aureus, 336 Enterococcus faecalis, 257 Enterococcus faecium ve 126 Stenotrophomonas maltophilia) çalıșmaya dahil edildi. Suşların tanımlanmasında Bruker Microflex MS (Bruker Daltonics, Bremen, Germany) sistemi kullanıldı. Antibiyotik duyarlılık sonuçları için Phoenix otomatize sistemi (BD, Sparks, MD, USA) ile elde edilen MiK değerleri, CLSI ve EUCAST kılavuzlarında belirtilen direnç sınır değerlerine göre yorumlandı.

Bulgular: Enterobacteriacea'da en yüksek direnç artışının beta laktam / beta-laktamaz inhibitör kombinasyonlarında, ardından sefalosporinler,

${ }^{1}$ Hacettepe University Medicine Faculty, Department of Medical Microbiology, Ankara

İletişim / Corresponding Author : Gülşen HAZIROLAN

Hacettepe Unv. Medicine Faculty, Dep. of Medical Microbiology, Sihhiye, Ankara - Türkiye

E-posta / E-mail :drgulsencetin@yahoo.com

DOI ID : 10.5505/TurkHijyen.2021.25428

Hazırolan G. Transition from CLSI to EUCAST: How our antibiotic susceptibility tests will be affected

Turk Hij Den Biyol Derg, 2021; 78(3): 287 - 298 
cephalosporins, quinolones and aminoglycosides. ESBL positive Enterobacteriaceae isolates were found more resistant to cephalosporins. The resistance rates of A. baumannii and $P$. aeruginosa seemed increased for quinolones, aminoglycosides and cephalosporins, however colistin resistance remained unchanged. All Gram-negative bacilli included in the study had decreased resistance rates for imipenem and meropenem. Similarly, S. maltophilia isolates had a decreased resistance rate for trimethoprim-sulfamethoxazole. While methicillin resistance rate did not change for $S$. aureus, minor changes were encountered for other antibiotic groups. There is no categorical changes observed at the susceptibility of enterococci to ampicillin, vancomycin, teicoplanin and linezolid.

Conclusion: Transition to EUCAST guideline in our hospital did not affect AST results of Gram- positive bacteria isolated from the patients in ICU. However, higher resistance rates were observed for all antibiotic groups except carbapenems in Gram- negative bacteria. As a result, following the current epidemiological data according to the standard used is of great importance in terms of determining the appropriate treatment.

Key Words: EUCAST, CLSI, antibiotic susceptibility tests kinolonlar ve aminoglikozitlerde olduğu görüldü. ESBL pozitif Enterobacteriaceae izolatlarının sefalosporinlere karşı daha dirençli olduğu bulundu. A. baumannii ve $P$. aeruginosa'nın direnç oranları kinolonlar, aminoglikozidler ve sefalosporinler için artmış görünse de kolistin için direnç değișmedi. Çalıșmaya dahil edilen tüm gram-negatif basillerde, imipenem ve meropenem için direnç oranları azaldı. Benzer șekilde, S. maltophilia izolatları trimetoprimsülfametoksazol için düşük direnç oranına sahipti. Metisilin direnç oranı S. aureus için değișmezken, diğer antibiyotik gruplarında minör değișikliklerle karşılașıldı. Enterokokların ampisilin, vankomisin, teikoplanin ve linezolide duyarlılığında kategorik bir değişiklik gözlenmedi.

Sonuç: Hastanemizde YBÜ hastalarından izole edilen gram pozitif bakterilerin ADT sonuçlarını EUCAST kılavuzuna geçiş etkilemedi. Ancak, gram-negatif bakterilerdeki karbapenemler hariç tüm antibiyotik grupları için daha yüksek direnç oranları gözlendi. Sonuç olarak, kullanılan standarda göre güncel epidemiyolojik verilerin takip edilmesi, uygun tedavinin belirlenmesi açısından büyük önem arz etmektedir.

Anahtar Kelimeler: EUCAST, CLSI, antibiyotik duyarlılık testi

\section{INTRODUCTION}

There is no national standards for evaluation of antibiotic susceptibility tests (AST) in our country. Therefore, most of the Clinical Microbiology Laboratories report their AST results according to Clinical Laboratory Standards Institute (CLSI) guideline. Nowadays, more and more laboratories prefer the guideline that has been published by European Committee on Antimicrobial Susceptibility Testing (EUCAST), due to free access on internet, translation of the documents into Turkish, and ease of sending suitable data to studies performed by Turkey- Europe partnership.

Changes in AST reports will affect the policies on antibiotic prescription and use (1). When the breakpoints of EUCAST guideline are used, it was reported that mainly Gram-negative organisms were reported as more resistant to antimicrobials (2-6). The reasons for that are use of 1-3 dilutions lower clinical breakpoints for some antimicrobials in EUCAST, and omission or restriction of intermediate 
category on the grounds that they are not supported by pharmacokinetic and pharmacodynamic values and clinical data.

High antimicrobial resistance rates have been reported in the microorganisms isolated from the patients hospitalized in the intensive care units (ICUs) in our country (7). Appreciating the changes that will appear in the reports after transition from CLSI guideline to EUCAST guideline in this group of patients may give us information on the effects of this change on antibiotic prescription policies, hospital costs, and resistance epidemiology.

In this study, minimal inhibition concentration (MIC) values of the most frequently isolated Grampositive and Gram- negative microorganisms isolated from the patients hospitalized in ICU obtained by using Phoenix automated system (BD, Sparks, MD, USA) were evaluated according to CLSI and EUCAST guidelines $(8,9)$. This was to try to determine the changes that would appear in AST results.

\section{MATERIAL and METHOD}

Ankara Numune Training and Research Hospital, Turkey houses all clinics except Pediatrics and Pulmonology, it has 997 hospital beds, and 49,565 patients are hospitalized annually. There are 9 ICU with a total of 81 beds, including general ICU, Emergency Internal Medicine ICU, Emergency Surgery ICU, Surgery ICU, Anesthesia and Reanimation ICU, Neurology ICU, Neurosurgery ICU, Coronary ICU, and Cardiovascular Surgery ICU. A total of 6294 patients were hospitalized in ICUs in 2017. The identifications of the microorganisms were performed with Bruker Microflex MS (Bruker Daltonics, Bremen, Germany) system, and their AST were evaluated with Phoenix automated system (BD, Sparks, MD, USA). Nonduplicated 5003 strains isolated from the samples sent from patients in ICU were included in the study. Isolated strains included 1261 Acinetobacter baumannii, 994 Escherichiae coli, 697 Pseudomonas aeruginosa, 546 Klebsiella pneumoniae, 424
Staphylococcus aureus, 336 Enterococcus faecalis, 257 Enterococcus faecium, 126 Stenotrophomonas maltophilia, 103 Proteus mirabilis, 97 Enterobacter cloacae, 90 Serratia marcescens, 45 Morganella morganii, and 27 Enterobacter aerogenes isolates, in rank order.

BD Phoenix Gram-negative NMIC-99, Uriner Gramnegative UNMIC-200 and Gram-positive PMIC-79 panels were used for determination of AST results. MIC values were retrospectively analyzed using EpiCenter (BD Biosciences, Sparks, MD, USA), which is the information management system of Phoenix automated system. The susceptibility patterns of the microorganisms studied were determined according to both CLSI and EUCAST guidelines' clinical breakpoints, and compared $(8,9)$.

The susceptibilities for aztreonam, norfloxacin, netilmicin, as well as high- level aminoglycoside susceptibilities were left out of assessment since the antibiotic concentrations tested in Phoenix AST cards did not contain the breakpoints given in EUCAST guideline.

Escherichiae coli ATCC 25922, Staphylococcus aureus ATCC 29213, Pseudomonas aeruginosa ATCC 27853 and Klebsiella pneumonia ATCC 700603 was used as quality control.

Statistical analysis of data was performed using SPSS 15.0 package program. The correlations of the categorical variables were analyzed with chi-square test. Statistical significance was set at $\mathrm{p}=0.05$.

\section{RESULTS}

Comparison of CLSI and EUCAST guidelines for susceptibility categories according to their clinical breakpoints are presented in Table 1. EUCAST does not have an intermediate category to simplify the tables. In order to compare two guidelines easily, clinical breakpoints of EUCAST are presented in CLSI format in Table 1. 
Table 1. Comparison of CLSI and EUCAST guidelines for susceptibility categories according to their clinical breakpoints for the most commonly isolated microorganisms from the patients in ICU

\begin{tabular}{|c|c|c|c|c|c|c|c|}
\hline \multirow[b]{2}{*}{ Species/drugs } & \multicolumn{3}{|c|}{ CLSI } & \multicolumn{3}{|c|}{ EUCAST } & \multirow[b]{2}{*}{$P$-value } \\
\hline & $\mathbf{S}$ & I & $\mathbf{R}$ & $\mathbf{S}$ & I & $\mathbf{R}$ & \\
\hline \multicolumn{8}{|l|}{ Escherichia coli $(\mathrm{n}=994)$} \\
\hline Ampicillin-sulbactam & 39.6 & 18.0 & 42.4 & 39.6 & - & 60.6 & $<0.001$ \\
\hline Amoxicillin-clavulanate & 59.3 & 15.1 & 25.6 & 59.3 & - & 40.7 & $<0.001$ \\
\hline Piperacillin-tazobactam & 75.4 & 2.6 & 22.0 & 71.8 & 3.6 & 24.6 & 0.142 \\
\hline Ticarcillin- clavulanate & 42.1 & 24.5 & 33.4 & 35.3 & 6.8 & 57.9 & $<0.001$ \\
\hline Cefepime & 56.3 & 8.1 & 35.6 & 53.3 & - & 40.1 & $<0.001$ \\
\hline Ceftazidime & 66.7 & 6.4 & 26.9 & 56.0 & 10.7 & 33.3 & $<0.001$ \\
\hline Ceftriaxone & 50.1 & 0.6 & 49.3 & 50.1 & 0.6 & 49.3 & 1.000 \\
\hline Cefuroxime & 51.9 & 3.7 & 44.4 & 51.9 & - & 48.1 & $<0.001$ \\
\hline Ertapenem & 88.9 & 0.9 & 10.2 & 88.9 & 0.9 & 10.2 & 1.000 \\
\hline Imipenem & 86.6 & 5.6 & 7.8 & 92.2 & 4.0 & 3.8 & $<0.001$ \\
\hline Meropenem & 91.2 & 1.5 & 7.3 & 92.7 & 3.7 & 3.6 & $<0.001$ \\
\hline Ciprofloxacin & 53.2 & 1.2 & 45.6 & 52.2 & 1.0 & 46.8 & 0.805 \\
\hline Levofloxacin & 53.6 & 1.0 & 45.8 & 52.1 & 1.1 & 46.8 & 0.834 \\
\hline Amikacin & 97.9 & 0.2 & 1.9 & 95.1 & 2.8 & 2.1 & $<0.001$ \\
\hline Gentamicin & 78.6 & 0.1 & 21.3 & 57.7 & 20.9 & 21.4 & $<0.001$ \\
\hline Trimethoprim sulfamethoxazole & 54.8 & 0 & 45.2 & 54.8 & 0.5 & 44.7 & 0.081 \\
\hline \multicolumn{8}{|l|}{ Klebsiella pneumoniae $(\mathrm{n}=325)$} \\
\hline Ampicillin-sulbactam & 31.7 & 4.4 & 63.9 & 31.7 & - & 68.3 & $<0.001$ \\
\hline Amoxicillin-clavulanate & 39.3 & 19.1 & 41.6 & 39.3 & - & 60.7 & $<0.001$ \\
\hline Piperacillin-tazobactam & 52.0 & 8.6 & 39.4 & 45.0 & 7.0 & 48 & 0.085 \\
\hline Ticarcillin- clavulanate & 33.7 & 11.2 & 55.1 & 32.0 & 1.07 & 66.3 & $<0.001$ \\
\hline Cefepime & 49.7 & 4.9 & 45.4 & 48.5 & 3.2 & 48.3 & 0.428 \\
\hline Ceftazidime & 48.4 & 6.2 & 45.4 & 44.8 & 3.6 & 51.6 & 0.160 \\
\hline Ceftriaxone & 43.4 & 0.4 & 56.2 & 43.4 & 0.4 & 56.2 & 1.000 \\
\hline Cefuroxime & 32.6 & 7.9 & 59.5 & 32.6 & - & 67.4 & $<0.001$ \\
\hline Ertapenem & 65.8 & 1.1 & 33.1 & 65.8 & 1.1 & 33.1 & 1.000 \\
\hline Imipenem & 65.1 & 8.8 & 26.1 & 73.9 & 14.2 & 11.9 & $<0.001$ \\
\hline Meropenem & 72.8 & 7.8 & 19.4 & 80.6 & 6.7 & 12.7 & 0.047 \\
\hline Ciprofloxacin & 53.4 & 5.9 & 40.4 & 51.6 & 1.8 & 46.6 & 0.016 \\
\hline Levofloxacin & 60 & 2.7 & 37.3 & 59.0 & 1.0 & 40 & 0.188 \\
\hline Amikacin & 93.8 & 0.6 & 5.6 & 90.6 & 3.2 & 6.2 & 0.060 \\
\hline Gentamicin & 69 & - & 31.0 & 59.5 & 9.5 & 31.0 & $<0.001$ \\
\hline Trimethoprim sulfamethoxazole & 48.6 & - & 51.4 & 48.6 & 1.8 & 49.6 & 0.047 \\
\hline
\end{tabular}


Table 1 (cont). Comparison of CLSI and EUCAST guidelines for susceptibility categories according to their clinical breakpoints for the most commonly isolated microorganisms from the patients in ICU

\begin{tabular}{|c|c|c|c|c|c|c|c|}
\hline \multirow{2}{*}{ Species/drugs } & \multicolumn{3}{|c|}{ CLSI } & \multicolumn{3}{|c|}{ EUCAST } & \multirow[b]{2}{*}{$P$-value } \\
\hline & $\mathbf{S}$ & I & $\mathbf{R}$ & $\mathbf{S}$ & I & $\mathbf{R}$ & \\
\hline \multicolumn{8}{|l|}{ Acinetobacter baumannii $(n=1261)$} \\
\hline Imipenem & 7.3 & 0.4 & 92.3 & 7.3 & 2.4 & 90.3 & $<0.001$ \\
\hline Meropenem & 6.8 & 0.2 & 93 & 6.8 & 2.3 & 90.9 & $<0.001$ \\
\hline Ciprofloxacin & 6.4 & 0.2 & 93.4 & 6.4 & 0.2 & 93.4 & 1.000 \\
\hline Levofloxacin & 6 & 7.6 & 86.4 & 5.9 & 0.1 & 94 & $<0.001$ \\
\hline Amikacin & 12.7 & 3 & 84.3 & 11.5 & 1.2 & 87.3 & 0.003 \\
\hline Gentamicin & 17.8 & 7.9 & 74.3 & 17.8 & - & 82.2 & $<0.001$ \\
\hline Netilmicin & 53.9 & - & 46.1 & 53.9 & - & 46.1 & 1.000 \\
\hline Colistin & 98.9 & - & 1.1 & 98.9 & - & 1.1 & 1.000 \\
\hline Trimethoprim sulfamethoxazole & 27.5 & - & 72.5 & 27.5 & - & 72.5 & 1.000 \\
\hline \multicolumn{8}{|l|}{ Pseudomonas spp. ( $n=697)$} \\
\hline Piperacillin-tazobactam & 52.0 & 7.1 & 40.9 & 52.0 & - & 48.0 & $<0.001$ \\
\hline Ticarcillin- clavulanate & 25 & 17.7 & 57.3 & 25 & - & 75 & $<0.001$ \\
\hline Cefepime & 54.8 & 12.4 & 32.8 & 54.8 & - & 45.2 & $<0.001$ \\
\hline Ceftazidime & 54.8 & 4.6 & 40.6 & 54.8 & - & 45.2 & $<0.001$ \\
\hline Imipenem & 46.8 & 2.3 & 50.9 & 49.1 & 5.3 & 45.6 & 0.005 \\
\hline Meropenem & 43.2 & 12.7 & 44.1 & 55.9 & 7.9 & 36.2 & $<0.001$ \\
\hline Ciprofloxacin & 52.1 & 7.8 & 40.1 & 46.2 & 5.9 & 47.9 & 0.010 \\
\hline Levofloxacin & 47.5 & 10.1 & 42.4 & 40.1 & 7.4 & 52.5 & 0.001 \\
\hline Amikacin & 73.6 & 10.1 & 16.3 & 68.8 & 4.8 & 26.4 & $<0.001$ \\
\hline Gentamicin & 59.5 & 3.2 & 37.3 & 59.5 & - & 40.5 & $<0.001$ \\
\hline Netilmicin & 91.7 & 8.3 & - & 58.3 & - & 41.7 & $<0.001$ \\
\hline Colistin & 98.3 & 1.1 & 0.6 & 99.4 & - & 0.6 & 0.018 \\
\hline \multicolumn{8}{|l|}{ Staphylococcus aureus $(\mathrm{n}=424)$} \\
\hline Penicillin & 10.5 & - & 89.5 & 10.5 & - & 89.5 & 1.000 \\
\hline Cefoxitin & 73.9 & & 26.1 & 73.9 & & 26.1 & 1.000 \\
\hline Ciprofloxacin & 77.2 & 0.3 & 25.5 & 77.2 & - & 22.8 & 0.404 \\
\hline Levofloxacin & 98.9 & 1.1 & - & 98.9 & 1.1 & - & 1.000 \\
\hline Vancomycin & 100 & - & - & 100 & - & - & 1.000 \\
\hline Teicoplanin & 100 & - & - & 100 & - & - & 1.000 \\
\hline Erythromycin & 75.8 & 1.1 & 23.1 & 75.1 & 0.7 & 24.2 & 0.727 \\
\hline Clindamycin & 96.7 & 0.9 & 2.4 & 24.5 & 72.2 & 3.3 & $<0.001$ \\
\hline Quinupristin-dalfopristin & 100 & - & - & 100 & - & - & 1.000 \\
\hline Tetracycline & 71.8 & - & 28.2 & 71 & 0.8 & 28.2 & 0.221 \\
\hline Linezolid & 99.7 & - & 0.3 & 98.2 & - & 1.8 & 0.019 \\
\hline Trimethoprim sulfamethoxazole & 100 & - & - & 100 & - & - & 1.000 \\
\hline
\end{tabular}


Table 1 (cont). Comparison of CLSI and EUCAST guidelines for susceptibility categories according to their clinical breakpoints for the most commonly isolated microorganisms from the patients in ICU

\begin{tabular}{|c|c|c|c|c|c|c|c|}
\hline \multirow[b]{2}{*}{ Species/drugs } & \multicolumn{3}{|c|}{ CLSI } & \multicolumn{3}{|c|}{ EUCAST } & \multirow[b]{2}{*}{$P$-value } \\
\hline & $\mathbf{S}$ & I & $\mathbf{R}$ & $S$ & I & $\mathbf{R}$ & \\
\hline \multicolumn{8}{|c|}{ Enterococcus faecium $(\mathrm{n}=336)$} \\
\hline Ampicillin & 9.2 & - & 90.8 & 9.2 & - & 90.8 & 1.000 \\
\hline Teicoplanin & 80.9 & - & 19.1 & 80.9 & - & 19.1 & 1.000 \\
\hline Vancomycin & 79.9 & - & 20.1 & 79.9 & - & 20.1 & 1.000 \\
\hline Linezolid & 100 & - & - & 100 & - & - & 1.000 \\
\hline \multicolumn{8}{|c|}{ Enterococcus faecalis $(\mathrm{n}=257)$} \\
\hline Ampicillin & 94.4 & - & 5.1 & 94.4 & - & 5.1 & 1.000 \\
\hline Teicoplanin & 98.4 & - & 1.6 & 98.1 & - & 1.9 & 1.000 \\
\hline Vancomycin & 98.4 & - & 1.6 & 98.1 & - & 1.9 & 1.000 \\
\hline Linezolid & 100 & - & - & 100 & - & - & 1.000 \\
\hline
\end{tabular}

Enterobacteriaceae species: When the differences between CLSI and EUCAST were reviewed in general, all isolates reported as intermediate category according to CLSI were observed as resistant in EUCAST since there was no "intermediate category" option for ampicillin-sulbactam or amoxicillinclavulanate in EUCAST. However, the rate of the susceptible isolates remained the same. All isolates that were reported as intermediate category for ampicillin-sulbactam or amoxicillin-clavulanate with CLSI were determined as resistant with EUCAST. Since the values observed for cephalosporins, quinolones and aminoglycosides by EUCAST were 1-3 dilutions lower compared to $\mathrm{CLSI}$, resistance rates to those groups of antimicrobials were found higher with EUCAST. The only group with a decreased resistance rate for Enterobacteriaceae species was carbapenems (imipenem and meropenem). The susceptibility patterns for ceftriaxone and ertapenem remained the same since their clinical breakpoints were the same in two guidelines.

E. coli: When EUCAST guideline was compared with CLSI, the significant increase for resistance was seen in beta lactam-beta lactamase inhibitor combinations $(p<0.05)$. Cefepime, ceftazidime, and cefuroxime resistance increased from $35.6 \%, 26.9 \%$ and $44.4 \%$, to $40.1 \%, 33.3 \%$ and $48.1 \%$, respectively $(p<0.05)$. No differences were seen in ceftriaxone, ertapenem and trimethoprim-sulfamethoxazole resistance rates, however the resistance rates of the antimicrobials in quinolone and aminoglycoside groups increased by $0.1-1.1 \%(p<0.05)$. The resistance for imipenem and meropenem decreased from $7.8 \%$ and $7.3 \%$, to $3.8 \%$ and $3.6 \%$ respectively $(p<0.05)$.

$K$. pneumoniae: Similar changes with $E$. coli isolates were seen in those isolates. The resistance isolates for imipenem and meropenem appeared decreased with use of EUCAST guideline when compared to CLSI, and the isolates reported as susceptible increased from $65.1 \%$ and $72.8 \%$, to $73.9 \%$ and $80.6 \%$, respectively $(p<0.05)$.

P. mirabilis: The most important resistance change was seen for quinolones in this microorganism. The resistance for ciprofloxacin was $27.1 \%$ with CLSI while it was $56.5 \%$ with EUCAST $(p<0.05)$. The susceptibility rate for levofloxacin decreased from $74.6 \%$ to $40 \%$ due to the isolates switched to intermediate category $(p<0.05)$. 
S. marcescens: The most appreciable changes for this microorganism were seen for meropenem and ciprofloxacin. The resistance decreased from $25.0 \%$ to $4.0 \%$ due to switch of $S$. marcescens isolates resistant to meropenem with CLSI to intermediate category with EUCAST guideline $(p<0.05)$. The resistance rate increased mildly in ciprofloxacin, and sensitivity decreased from $90.9 \%$ to $64.9 \%$ since some sensitive isolates switched to moderately sensitive category with EUCAST $(p<0.05)$.

M. morganii: The resistance increase from $19.0 \%$ to $69.0 \%$ due to switch of all isolates reported as intermediate category to ampicillin-sulbactam in CLSI to resistant category with EUCAST. The resistance rates for ciprofloxacin and levofloxacin increased from $7.1 \%$ and $0 \%$, to $21.4 \%$ and $24.3 \%$, respectively $(p<0.05)$. The resistance rates did not increase for any of the other antimicrobials tested.

E. cloacae and E. aerogenes: Susceptibility patterns of these bacteria for ceftriaxone, ceftazidime and cefuroxime did not change. Resistance to cefepime increased from $13.3 \%$ and $8.3 \%$, to $14.4 \%$ and $16.7 \%$ in $E$. cloacae and $E$. aerogenes, respectively $(p<0.05)$. Imipenem resistance rates were found as $20.2 \%$ and $8.3 \%$, respectively according to CLSI, and as $5.6 \%$ and $4.2 \%$, respectively according to EUCAST $(p<0.05)$.

A. baumannii: There were no differences between EUCAST and CLSI guidelines for ciprofloxacin, netilmicin, colistin and trimethoprimsulfamethoxazole in $A$. baumanii isolates. The resistance rates for levofloxacin, amikacin and gentamicin increased from $86.4 \%, 84.3 \%$ and $74.3 \%$, to $94.0 \%, 87.3 \%$ and $82.2 \%$, respectively with EUCAST $(p<0.05)$. Higher clinical breakpoints for imipenem and meropenem in EUCAST resulted in a decrease in imipenem and meropenem resistance rates, from $92.3 \%$ and $93 \%$, to $90.3 \%$ and $90.9 \%$, respectively $(p<0.05)$.

P. aeruginosa: Susceptibility to colistin remained the same in $P$. aeruginosa isolates due to the same clinical breakpoints in two guidelines. However, higher resistance rates were found for all antimicrobials except imipenem and meropenem with EUCAST $(p<0.05)$. No resistance was determined for netilmicin in any of those isolates with CLSI, however resistance rate was observed as $41.7 \%$ with EUCAST $(p<0.05)$.

S. maltophilia: EUCAST has observed a clinical breakpoint only for trimethoprim- sulfamethoxazol for S. maltophilia, and this value is higher than CLSI. Therefore, $91.9 \%$ of the isolates were found as susceptible and $8.1 \%$ of them were found resistant with CLSI while $96.4 \%$ of the isolates were observed as susceptible and $3.6 \%$ of them were found resistant with EUCAST $(p<0.05)$.

S. aureus: All S. aureus isolates were found susceptible to teicoplanin, vancomycin, quinupristindalfopristin and trimethoprim- sulfamethoxazole both with CLSI and EUCAST guidelines. No differences were observed in the resistance rates to penicillin, levofloxacin, tetracycline or cefoxitin. A minor increase was seen in the resistance rates to erythromycin and clindamycin. The most important change was seen in the susceptibility rate to clindamycin. The susceptibility rate of clindamycin decreased from $96.7 \%$ with CLSI to $24.5 \%$ with EUCAST $(p<0.05)$.

E. faecium and $E$. faecalis: There is no categorical changes observed at the susceptibility of enterococci to ampicillin, vancomycin, teicoplanin and linezolid.

ESBL positive Enterobacteriaceae isolates: CLSI and EUCAST revoked the decision that "all isolates found ESBL positive according to combined synergy test results should be reported resistant to all cephalosporins and monobactams", lowered the clinical breakpoints, and requested that the reports to be written in line with those breakpoints. The differences between CLSI and EUCAST guidelines for reporting ESBL positive isolates as found by Phoenix system are presented in Table 2. ESBL rates were $57.2 \%(n=569)$ in $E$. coli isolates and $59.5 \%(n=325)$ in $K$. pneumonia isolates. There were no differences 
for ceftriaxone since the clinical breakpoints were the same in two guidelines, however significantly more isolates were reported resistant to cefepime, ceftazidime, and cefuroxime with EUCAST $(p<0.05)$.

\section{Potential \\ carbapenemase \\ producer}

Enterobacteriaceae isolates: A total of $164 \mathrm{~K}$. pneumoniae isolates (30\%) and $158 \mathrm{E}$. coli isolates (15.9\%) were found as potential carbapenemase producer by Phoenix system. The susceptibility results differences between CLSI and EUCAST guidelines for ertapenem, imipenem and meropenem are presented in Table 3. Higher clinical breakpoints for carbapenems in EUCAST guideline resulted with a decrease in imipenem and meropenem resistance rates for potential carbapenemase producer $(p<0.05)$.

Table 2. Comparison of CLSI and EUCAST guidelines for susceptibility categories according to their clinical breakpoints for cephalosporins in Enterobacteriacea isolates producing extended- spectrum beta-lactamase (ESBL)

\begin{tabular}{|c|c|c|c|c|c|c|c|}
\hline \multirow[b]{2}{*}{ Species/drugs } & \multicolumn{3}{|c|}{ CLSI } & \multicolumn{3}{|c|}{ EUCAST } & \multirow[b]{2}{*}{$P$-value } \\
\hline & $\mathrm{S}$ & I & $\mathbf{R}$ & $S$ & I & $\mathbf{R}$ & \\
\hline \multicolumn{8}{|c|}{ Escherichia coli $(\mathrm{n}=569)$} \\
\hline Cefepime & 13.2 & 15.9 & 70.9 & 7.6 & 13.2 & 79.1 & 0.002 \\
\hline Ceftazidime & 38.5 & 14.6 & 46.9 & 13.4 & 25.1 & 61.5 & $<0.001$ \\
\hline Cefuroxime & 0 & 4.8 & 95.2 & 0 & - & 100 & $<0.001$ \\
\hline Ceftriaxone & 4.2 & 0 & 95.8 & 4.2 & 0 & 95.8 & 1.000 \\
\hline \multicolumn{8}{|c|}{ K. pneumoniae $\quad(n=325)$} \\
\hline Cefepime & 9.8 & 8.9 & 81.3 & 5.7 & 7.3 & 87.0 & 0.108 \\
\hline Ceftazidime & 7.1 & 20.6 & 72.2 & 0 & 7.1 & 92.9 & $<0.001$ \\
\hline Cefuroxime & 0 & 0 & 100 & 0 & 0 & 100 & 1.000 \\
\hline Ceftriaxone & 2.4 & 0 & 97.6 & 2.4 & 0 & 97.6 & 1.000 \\
\hline
\end{tabular}

Table 3. Comparison of CLSI and EUCAST guidelines for susceptibility categories according to their clinical breakpoints for carbapenems in potential carbapenemase producer Enterobacteriacea isolates

\begin{tabular}{|c|c|c|c|c|c|c|c|}
\hline \multirow[b]{2}{*}{ Species/drugs } & \multicolumn{3}{|c|}{ CLSI } & \multicolumn{3}{|c|}{ EUCAST } & \multirow[b]{2}{*}{$P$-value } \\
\hline & $\mathbf{S}$ & I & $\mathbf{R}$ & $S$ & I & $\mathbf{R}$ & \\
\hline \multicolumn{8}{|c|}{ Escherichia coli $(\mathrm{n}=158)$} \\
\hline Ertapenem & 38.6 & 1.9 & 59.5 & 38.6 & 1.9 & 59.5 & 1.000 \\
\hline Imipenem & 24.1 & 30.4 & 45.5 & 54.4 & 22.2 & 23.4 & $<0.001$ \\
\hline Meropenem & 47.5 & 8.2 & 44.3 & 55.1 & 2., 5 & 23.4 & $<0.001$ \\
\hline \multicolumn{8}{|c|}{ K. pneumoniae $\quad(n=164)$} \\
\hline Ertapenem & 15.3 & 1.2 & 83.5 & 15.3 & 1.2 & 83.5 & 1.000 \\
\hline Imipenem & 14.6 & 24.4 & 61.0 & 40.3 & 39.6 & 20.1 & $<0.001$ \\
\hline Meropenem & 36.6 & 21.3 & 4.1 & 57.9 & 18.3 & 23.8 & $<0.001$ \\
\hline
\end{tabular}




\section{DISCUSSION and CONCLUSION}

A number of laboratories in Turkey were transitioned from CLSI guideline to EUCAST guideline for interpretation of AST. This transition will affect AST results. Change in AST results may affect choice of empirical antibiotics, hospitals' isolation policies, and health costs may increase accordingly. Therefore, the changes that may occur must be known.

In our hospital, the AST results of the microorganisms isolated from the patients who admit to outpatient clinics are reported according to disk diffusion method. However, the results of the patients in ICU where more resistant isolates are seen are reported as MIC values, as determined by Phoenix automated system. Determination of MIC with manual microdilution method is hard in laboratories where many bacteria and antimicrobials are studied. Therefore, laboratories prefer automated antibiotic susceptibility test devices. Giani et al. analyzed the performance of Phoenix system, and reported that experimental agreement (concordance of MIC value) and categorical agreement (susceptible, intermediate category, resistant) were $97.3 \%$ and $95.2 \%$, respectively, and the results fitted ISO 20776:2007 criteria (10). In this study, the MIC values determined by Phoenix system were interpreted according to EUCAST, and the changes in susceptibility categories were evaluated.

Resistance rates did not change for ceftriaxone and ertapenem in Enterobacteriaceae since the clinical breakpoints were the same in two guidelines. Previous studies reported that resistance rates of Gram- positive bacteria did not significantly change after transition from CLSI to EUCAST, however increased resistance was seen in Gram-negative bacteria particularly in cephalosporin, carbapenem and quinolone groups $(2-4,11)$.

The reason for the highest resistance increase in beta- lactam/ beta- lactamase combinations is omission of the intermediate category in EUCAST for those antibiotics. Although the rate of susceptible isolates remained the same, the number of resistant isolates increased for this group of antibiotics. Since EUCAST guideline reported the breakpoints of cephalosporins, quinolones, and aminoglycosides 1-3 dilutions lower for Enterobacteriacea isolates, different rates of resistance increase were observed in those isolates. Previous studies reported a significant decrease in quinolone susceptibility after transition to EUCAST guideline particularly in P.mirabilis and M. morganii, and stated that those antibiotics would be preferred less for treatment. Rodriguez-Martinez et al. established that $E$. coli isolates that carry quinolone resistance genes were reported as resistant with EUCAST guideline while they were reported as susceptible or intermediate category with CLSI guideline (12). Previous CLSI- EUCAST comparison studies done with disk diffusion method reported a higher resistance rate for carbapenems with EUCAST guideline, however the only antibiotic group that showed a decrease in resistance was carbapenems with EUCAST in our study $(2,3)$. We suppose that carbapenem susceptibility will be established more for Enterobacteriaceae, A. baumanii and $P$. aeruginosa with EUCAST, and carbapenems will be increasingly preferred particularly for treatment of the infections caused with multi- drug resistant isolates.

CLSI and EUCAST omitted the rule of reporting resistant after ESBL phenotypic verification tests, changed zone diameter and MIC values, and suggested that the results should be given according to those without taking the verification tests into account. The reason for this is to prevent increased preference of carbapenems when cephalosporins cannot be used, and attempting to prevent selection of carbapenemresistant isolates (13). This change increased the number of the strains reported as susceptible despite ESBL positivity $(14-16,17)$. It was seen that the isolates determined as ESBL- positive with Phoenix were reported to be more resistant to cephalosporins with EUCAST. This will cause less preference of cephalosporins in treatment after transition to 
EUCAST guideline, and carbapenems may be used more frequently since increased susceptibility is reported for carbapenems in this guideline. On the other hand, it was reported that the reports prepared according to EUCAST guideline had a better correlation with clinic $(9,14,15,18)$.

A. baumanii isolates isolated frequently in ICU patients in our hospital are one of the most important problems due to multi- drug resistance. Usually, colistin is the only treatment option in those isolates. We did not determine a change in colistin resistance in $A$. baumanii isolates since breakpoints for colistin are the same in CLSI and EUCAST guidelines. Alreadyhigh resistance rates for other antibiotics increased some more. Although a small decrease was observed in imipenem and meropenem resistance, those isolates moved into intermediate category, and no change was observed in susceptibility rates. It was considered that colistin would remain to be the only option for treatment in those isolates after transition to EUCAST guideline.

$P$. aeruginosa isolates showed increased resistance to a number of antibiotics with EUCAST guideline, and it was supposed that the rate of multi- drug resistant isolates would further increasE. colistin resistance remained the same, however a significant increase was seen in carbapenem susceptibility.

There was no change in MRSA rate since clinical breakpoints were the same in two guidelines for cefoxitin in $S$. aureus isolates. Although clinical resistance breakpoints are 2-3 dilutions lower for vancomycin and teicoplanin in EUCAST guideline, no glycopeptide- resistant $S$. aureus isolates were observed. The susceptibility patterns of other studied antibiotics did not show any differences. It was supposed that no change would be observed in treatment options for Gram- positive bacteria with use of EUCAST guideline.

Studies that compared the guidelines according to the results of disk diffusion results could not report the results for piperacillin-tazobactam and ceftazidim since the disk contents were different in two guidelines $(2,4)$. We could determine the change for those antibiotics since we used MIC results in this study. Another difference of our study is its performance in a region where high resistance rates are seen.

This study has a limitation. There is no molecular detection could performed for carbapenem and quinolone resistance gene. These information may be important to microbiologists make a decision for antimicrobial therapy.

In conclusion, use of EUCAST guideline will result in an increase in the number of multi- drug resistant microorganisms except carbapenems due to increased resistance in all antimicrobial groups in Gram-negative bacteria. This may cause performing more verification tests in laboratories, change of antibiotic preferences, an increase in the number of isolated patients, and as a result, increased health costs. However, EUCAST standards are wellsupported by pharmacodynamic- pharmacokinetic studies. Free access on internet, translation of the documents into Turkish, and ease of comparison of data in studies performed by Turkey- Europe partnership are other advantages of this guideline. The differences between two guidelines remain to be compared with evidence- based clinical studies. Determination of resistance changes after transition to EUCAST guideline will result in reviewing antibiotic notification and preference policies, and help to control development of resistance. 


\section{ETHICS COMITTEE APPROVAL}

* This study does not require Ethics Committee Approval.

\section{CONFLICT OF INTEREST}

The authors declare no conflict of interest.

\section{REFERENCES}

1. MacKenzie FM, Gould IM, Bruce J, Mollison J, Monnet DL, Krcmery V. et al. The role of microbiology and pharmacy departments in the stewardship of antibiotic prescribing in European hospitals. J Hosp Infect, 2007; 65 (2): 73-81.

2. Hombach M, Bloemberg GV, Böttger ECJ. Effects of clinical breakpoint changes in CLSI guidelines 2010/2011 and EUCAST guidelines 2011 on antibiotic susceptibility test reporting of Gramnegative bacilli. Antimicrob Chemother. 2012; 67 (3): 622-32.

3. Hombach M, Wolfensberger A, Kuster SP, Böttger EC. Influence of clinical breakpoint changes from CLSI 2009 to EUCAST 2011 antimicrobial susceptibility testing guidelines on multidrug resistance rates of Gram-negative rods. J Clin Microbiol 2013; 51 (7): 2385-87.

4. Wolfensberger A, Sax H, Weber R, Zbinden R, Kuster SP, Hombach M. Change of antibiotic susceptibility testing guidelines from CLSI to EUCAST: influence on cumulative hospital antibiograms. PLoS One. 2013; 8 (11) :e79130.

5. Van der Bij AK, Van Dijk K, Muilwijk J, Thijsen SF, Notermans DW, de Greeff S, et al. Clinical breakpoint changes and their impact on surveillance of antimicrobial resistance in Escherichia coli causing bacteraemia. Clin Microbiol Infect. 2012; 18 (11): 466-72.
6. Hawser SP, Badal RE, Bouchillon SK, Hoban DJ, Hsueh PR. Comparison of CLSI 2009, CLSI 2010 and EUCAST cephalosporin clinical breakpoints in recent clinical isolates of Escherichia coli, Klebsiella pneumoniae and Klebsiella oxytoca from the SMART Global Surveillance Study. Int J Antimicrob Agents. 2010; 36 (3): 293-94.

7. Gür D, Gülay Z, Akan OA, Aktaș Z, Kayacan $\mathrm{CB}$, Cakici $\mathrm{O}$, et al. Resistance to newer betalactams and related ESBL types in gram-negative nosocomial isolates in Turkish hospitals: results of the multicentre HITIT study. Mikrobiyol Bul 2008; 42 (4): 537-44.

8. Clinical and Laboratory Standards Institute. 2017. M100 Performance standards for antimicrobial susceptibility testing: 27rd informational supplement. Clinical and Laboratory Standards Institute, Wayne, PA.

9. The European Committee on Antimicrobial Susceptibility Testing. Breakpoint tables for interpretation of MICs and zone diameters. Version 7.1, 2017. http://www.eucast.org.

10. Giani T, Morosini MI, D’Andrea MM, GarcíaCastillo M, Rossolini GM, Cantón R. Assessment of the Phoenix ${ }^{\mathrm{TM}}$ automated system and EUCAST breakpoints for antimicrobial susceptibility testing against isolates expressing clinically relevant resistance mechanisms. Clin Microbiol Infect. 2012; 18: (11): 452-58. 
11. Marchese A, Esposito S, Barbieri R, Bassetti $M$, Debbia E. Does the adoption of EUCAST susceptibility breakpoints affect the selection of antimicrobials to treat acute community-acquired respiratory tract infections? BMC Infect Dis. 2012; 12 (16): 181.

12. Rodríguez-Martínez JM, Briales A, Velasco C, Díaz de Alba P, Martínez-Martínez L, Pascual A. Discrepancies in fluoroquinolone clinical categories etween the European Committee on Antimicrobial Susceptibility Testing (EUCAST) and CLSI for Escherichia coli harbouring qnr genes and mutations in gyrA and parC. J Antimicrob Chemother. 2011; 66 (6): 1405-07.

13. Masterton RG. The new treatment paradigm and the role of carbapenems. Int J Antimicrob Agents. 2009; 33 (2): 105-10.

14. Rodríguez-Baño J, Picón E, Navarro MD, LópezCerero L, Pascual A, ESBL-REIPI Group. Impact of changes in CLSI and EUCAST breakpoints for susceptibility in bloodstream infections due to extended-spectrum B-lactamase-producing Escherichia coli. Clin Microbiol Infect. 2012; 18 (9): 894-900.
15. Wang $P$, Hu F, Xiong $Z$, Ye $X$, Zhu D, Wang YF et al. Susceptibility of extended- spectrum- betalactamase- producing Enterobacteriaceae according to the new CLSI breakpoints. J Clin Microbiol. 2011; 49 (9): 3127-131.

16. Polsfuss S, Bloemberg GV, Giger J, Meyer V, Hombach M. Comparison of European Committee on Antimicrobial Susceptibility Testing (EUCAST) and CLSI screening parameters for the detection of extended-spectrum B-lactamase production in clinical Enterobacteriaceae isolates. J Antimicrob Chemother. 2012; 67 (1): 159-66.

17. Kaki R, Elligsen $M$, Walker S, Simor A, Palmay L, Daneman N. Impact of antimicrobial stewardship in critical care: a systematic review. J Antimicrob Chemother. 2011; 66 (6): 1223-230.

18. Kassim A, Omuse G, Premji Z, Revathi G. Comparison of Clinical Laboratory Standards Institute and European Committee on Antimicrobial Susceptibility Testing guidelines for the interpretation of antibiotic susceptibility at a University teaching hospital in Nairobi, Kenya: a cross-sectional study. Ann Clin Microbiol Antimicrob 2016; (11): 15-21. 